\title{
Yat Kaptanlarının İşe Yabancılaşmaları ve İşten Ayrılma Niyetlerinde Kontrol Odağının Düzenleyici Etkisi (The Effect of Locus of Control on Alienation and Intention to Leave of Yacht Captains)
}

\section{Murat YORULMAZ iD a Figen SEVINÇ iD $b$}

a Kocaeli Üniversitesi, Denizcilik Fakültesi, Denizcilik İşletmeleri Yönetimi Bölümü, Kocaeli, Türkiye. murat.yorulmaz@kocaeli.edu.tr

b Bartın Üniversitesi, Bartın Meslek Yüksekokulu, Seyahat, Turizm ve Eğlence Hizmetleri Bölümü, Bartın, Türkiye. $\underline{\text { fsevinc@bartin.edu.tr }}$

\begin{tabular}{|c|c|}
\hline MAKALE BİLGİSİ & ÖZET \\
\hline $\begin{array}{l}\text { Anahtar Kelimeler: } \\
\text { Yat kaptanı } \\
\text { Yat işletmesi } \\
\text { İşe yabancılaşma }\end{array}$ & $\begin{array}{l}\text { Amaç - Bu çalışmanın amacı, işe yabancılaşmanın ve kontrol odağının, işten ayrılma niyetine olan } \\
\text { etkisini ve işe yabancılaşma ile işten ayrılma niyeti arasındaki ilişkide içsel ve dışsal kontrol } \\
\text { odağının düzenleyici etkisinin olup olmadığını yat kaptanları örnekleminde incelemektir. } \\
\text { Araştırmanın bir diğer amacı da yat kaptanlarının içsel ve dışsal kontrol odakları arasındaki farkın } \\
\text { ortaya çıarılmasıdır. }\end{array}$ \\
\hline $\begin{array}{l}\text { İşten ayrılma niyeti } \\
\text { Kontrol odağ1 }\end{array}$ & $\begin{array}{l}\text { Yöntem - Çalışmanın amaçları doğrultusunda } 390 \text { yat kaptanına yüz yüze anket uygulanmış ve } \\
\text { toplanan veriler SPSS } 22 \text { ve AMOS } 22 \text { istatistiksel paket programlarının yardımıla analiz edilmiştir. }\end{array}$ \\
\hline $\begin{array}{l}\text { Gönderilme Tarihi } 24 \text { Şubat } \\
2020\end{array}$ & $\begin{array}{l}\text { Bulgular - Elde edilen bulgular sonucunda, yat kaptanlarının işten ayrılma niyetlerindeki değişimin } \\
\text { \% } 24^{\prime} \text { ünün işe yabancılaşma ve kontrol odağının birlikte açıkladığı ortaya çıkmıştır. Bunun yanı sıra } \\
\text { dışsal kontrol odağını, işe yabancılaşma ve işten ayrılma niyeti arasındaki ilişkide düzenleyici bir } \\
\text { etkisinin olduğu tespit edilmiştir. }\end{array}$ \\
\hline $\begin{array}{l}\text { Revizyon Tarihi } 22 \text { Mayis } 2020 \\
\text { Kabul Tarihi } 25 \text { Mayis } 2020\end{array}$ & $\begin{array}{l}\text { Tartışma - Yat turizminin önemli değerlerinden biri olan ve ticari yat mürettebatı hiyearşisinde en } \\
\text { üst mevkide yer alan yat kaptanlarının işe yabancılaşmaları ve işten ayrılma niyetlerini belirlemek } \\
\text { günümüz koşullarında yat işletmelerinin varlıklarını sürdürebilmeleri ve rekabet üstünlügüü } \\
\text { sağlayabilmeleri için oldukça önemlidir. Bununla birlikte yat kaptanlarının konumları ve }\end{array}$ \\
\hline $\begin{array}{l}\text { Makale Kategorisi: } \\
\text { Araştırma Makalesi }\end{array}$ & $\begin{array}{l}\text { sorumlulukları göz önüne alındığında bir kişilik özelliği olan kontrol odağının değerlendirilmesi } \\
\text { örgütsel açıdan yat işletmelerine fayda sağlamaktadır. }\end{array}$ \\
\hline
\end{tabular}

\begin{tabular}{ll}
\hline ARTICLE INFO & ABSTRACT \\
\hline $\begin{array}{l}\text { Keywords: } \\
\text { Yacht captain }\end{array}$ & $\begin{array}{l}\text { Purpose - The purpose of this study is to investigate the effect of alienation and locus of control on } \\
\text { intention to leave and whether there is an internal and external locus of control in the relationship } \\
\text { between alienation and intention to leave in the yacht captains sample. Another aim of the study is } \\
\text { to reveal the difference between the internal and external control foci of yacht captains. }\end{array}$ \\
Work alienation & $\begin{array}{l}\text { Design/methodology/approach - For the purposes of the study, } 390 \text { yacht captains were applied } \\
\text { face-to-face survey method and the data were analyzed with the help of SPSS } 22 \text { and AMOS } 22 \\
\text { Turnover intention }\end{array}$ \\
statistical package programs.
\end{tabular}




\section{Giriş}

Dünyada özellikle son yıllarda yat turizmine yönelik ilginin artması, yat turizmini oluşturan unsurların ön plana çıkmasına ve bu alana yönelik yatırımların yapılmasına olanak sağlamaktadır. Dolayısıyla dünyada ve Türkiye'de yat turizmini oluşturan unsurlar arasında yer alan yat işletmelerinin sayısında artış gözlenmekte ve hizmetleri çeşitlenmektedir. Yat işletmelerinde sunulan hizmetlerden biri olan ve yatların kullanım amacına göre adlandırılan ticari yatlarda (Sevinç ve Güzel, 2016), yat sahibi olmadan isteyen herkesin yat turizminden faydalanması sağlanmaktadır. Böylece yat ve yatçılık faaliyetlerinin daha fazla hedef kitleye ulaşmasına imkân tanınmakta, hizmetlerin nitelikleri değişmekte, işgörenlerin çalışma yaşamındaki önemi ön plana çıkmaktadır. Bu bağlamda, günümüz koşullarında yat işletmelerinin varlıklarını sürdürebilmeleri ve rekabet üstünlüğü sağlayabilmeleri çalışanların performansına bağlıdır. Yat turizminin en önemli değerlerinden biri olan ve ticari yat mürettebatı hiyearşisinde en üst mevkide yer alan yat kaptanlarının işe yabancılaşması, işten ayrılma niyetlerini etkileyebilmektedir. Ayrıca, işe yabancılaşma hissinin bireysel bir kontrole bağlı olduğu inancına sahip olarak içsel kontrol odağının yansımaları mümkün olabilmektedir. Bununla birlikte, işe yabancılaşmanın, bireysel kontrolün dışında geliştiğine dair inanca sahip olarak dışsal kontrol odağının etkisi de söz konusu olabilmektedir. Bu nedenle, mürettebatla ve turistlerle iletişimi sürekli ve yoğun olan yat kaptanlarının işe yabancılaşmaları işletmenin hedeflerine ulaşmasında engel teşkil edebilir, çalışma ortamını olumsuz etkileyebilir ve müşteri memnuniyetsizliğine sebep olabilir. Bu kapsamda çalışmanın amacı yat kaptanlarının işe yabancılaşma, işten ayrılma niyeti ve kontrol odakları arasındaki ilişkileri incelemek ve işe yabancılaşma ile işten ayrılma niyeti arasındaki ilişkide, içsel ve dışsal kontrol odağının düzenleyici etkisinin olup olmadığını yat kaptanları örnekleminde ortaya çıartmaktır. Araştırmanın amaçlarına yönelik olarak, ticari yatlarda çalışan 390 yat kaptanından yüz yüze anket tekniğiyle elde edilen veriler, açıklayııı ve doğrulayıı faktör analizleri, geçerlilik ve güvenilirlik analizleri, korelasyon analizleri ile hiyerarşik regresyon analizleri yardımıyla analiz edilmiştir.

Zamanla edilgen hale gelen çalışanın, işleyişe uyum sağlaması ve mevcut işleyişin değiştirilemez olduğuna dair bir inanca sahip olduğu düşünülmektedir (Budd, 2011; Saatcıŏlu ve Ukray, 2017). Hegel'e göre ise insanın yabancılaşması, ruhun karakteristik bir özelliğidir ve kendisi çabalayarak yabancılaşmanın üstesinden gelebilir (Sayers, 2009). Dolayısıyla, sosyoloji teorisinde önemli bir role sahip olan yabancılaşma kavramı, uzun yıllardır içsel ve dışsal kontrol odağı değişkenleriyle ilişkilendirilmektedir. Araştırmacılara göre, yabancılaşmış bireylerin kendi kaderlerini kontrol edemedikleri inancına sahip oldukları düşünülmektedir (Rotter, 1966). Buradan hareketle, işe yabancılaşma olgusu ve işten ayrılma niyeti arasındaki ilişkide, bir kişilik özelliği olan kontrol odağının içsel ve dışsal faktörlerinin düzenleyici etkisinin yat kaptanları açısından ele alınması ve incelenmesi önem taşımaktadır.

Özellikle son yıllarda turizm endüstrisinde ön plana çıan deniz turizmi ile doğrudan bağlantılı olan yat turizminin gün geçtikçe ilgi odağı haline geldiği, yat ve yatçılık ile ön plana çıkan destinasyonların ve sunulan hizmetlerin sayısının arttığı gözlenmektedir. Ancak, alanyazın incelendiğinde, araştırmaya konu olan değişkenleri birlikte ele alan ve yatçllık faaliyetlerinin bel kemiğini oluşturan nitelikteki işgörenleri araştıran bir çalışmaya rastlanamamıştır. Dolayısıyla, bu araştırma ile yat kaptanlarının işe yabancılaşma düzeylerinin işten ayrılma niyetine olan etkisinde, içsel ve dışsal kontrol odağının düzenleyici etkisinin olup olmadığının anlaşılması ve içsel ile dışsal kontrol odağı arasındaki anlamlı farklılıkların belirlenmesi açısından alanyazına katkı sağlayacağı düşünülmektedir.

\section{Literatür İncelemesi ve Hipotezler}

\section{1. İşe Yabancılaşma ve İşten Ayrulma Niyeti}

İnsanın olduğu tüm alanlarda ortaya çıkan yabancılaşma, hem çalışanların hem de örgütlerin karşılaşmak istemediği, çağdaş yönetim anlayışında, çalışan ilişkileri yönetimi açısından ele alınan bir kavram olarak karşımıza çıkmaktadır. Yabancılaşma kavramı, Hegel, Marx, Freud ve Fromm tarafından ele alınmış, yabancılaşma anlayışında insan ve emek bir ölçüt olarak değerlendirilmiş, insanın varoluşsal koşullarından kaynaklanan ihtiyaçlarını karşılayamama ve kendini gerçekleştirememe durumu çerçevesinde incelenmiştir (Fromm, 1990; Özyurt, 2016). Çünkü, bireylerin kendilerini gerçekleştirmeleri, emek vererek ortaya çıkardıkları ürüne bağlıdır. Buradan hareketle, diğer canlılarla insan arasındaki fark, emek ile belirtilmekte ve emek, insanın üretici gücü olarak görülmektedir (Özyurt, 2016). Bu durum ise emek sarfeden bireyin yaptığı işten bir doyum elde etme beklentisini doğurmaktadır. Fakat, Fromm’a göre (1990) modern çağda iş kavramı, 
değişikliğe uğramış doyum ve keyif vermek yerine bir görev olarak algılanmaya başlanmıştır. Dolayısıyla emek verilen işin, insanın kendini gerçekleştirme aracı olmaktan çıtığı, emek veren çalışanın ise edilgen bir duruma düşerek sağlıksız bir toplumda bireylerin zamanla daha fazla yabancılaştığı ifade edilmektedir (Fromm, 1990). Marx ise yabancılaşmayı, sadece çalışanın işine yönelik öznel bir memnuniyetsizlik olarak değil kapitalizmde insan kimliğini, tüm çalışanları etkileyen nesnel bir kayıp olarak görmektedir (Rockmore, 2002; Özyurt, 2016).

Alanyazın incelendiğinde, yabancılaşma kavramında sosyolojik, psikolojik, ekonomik, politik ve felsefi bir yaklaşım söz konusu olduğu (Tolan, 1981) işe yabancılaşmaya yönelik araştırmaların sosyo-psikolojik açıdan ele alındığı görülmektedir. Dolayısıyla, sosyo-psikolojik açıdan işe yabancılaşma, çalışanın işinden, bir toplumdan veya gruptan uzaklaşmasını ifade etmektedir ve kendini o işe, topluma ya da gruba ait hissetmemesine neden olmaktadır (Köksal, 2010). Bazı çalışmalarda hizmet sektörünün gelişmesi ve artan önemi sebebiyle işle ilgili kimliklere yönelik psikolojik ve sosyolojik yaklaşımların duygusal emek ile ilişkisi vurgulanmaktadır (Fromm, 1990; Budd, 2011; Develioğlu ve Tekin, 2012; Kaya ve Serçeoğlu, 2013: Usta ve Küçükaltan, 2014). Bunun bir sonucu olarak da çalışanların işine bakışaçısı, motivasyonu, performansı ve karar verme süreci örgütsel ve bireysel açıdan etkilenmektedir. Bu bağlamda Seeman (1967) tarafından beş farklı boyut olarak sınıflandırılan işe yabancılaşma olgusunun turizm işletmeleri açısından değerlendirilmesi mümkündür. Bunlar;

- Çalışanların iş süresince etkisinin ve kontrolünün olmadığı inancına "güçsüzlük boyutu",

- Çalışan amaçlarının işletme ile çelişmesi ve çalışanın işletmedeki eylemlere anlam verememesi durumu olan "anlamsizlik boyutu",

- Çalışanların kuralların etkisini kaybetmesi sebebiyle kendi yolunu belirlemesi ve işletmeye güvensizliğin oluşması durumuna "kuralsızlık boyutu"

- İşin çalışan açısından herhangi bir değer taşımaması, çalışanın işletme standartlarından uzaklaşmış hissetmesi durumuna "yalıtılma" diğer bir değişle "izole olma boyutu"

- Çalışanın işten ve kendinden doyum alamaması durumuna ise "kendinden uzaklaşma boyutu" olmak üzere araştırmacılar tarafından tanımlanmıştır (Dean, 1961; Seeman, 1967; Kohn, 1976).

Turizm işletmelerinin en güçlü kaynağı olan çalışanları örgütlerde etkin kılan güç, kendilerini gerçekleştirme hissine sahip olmaları ve iletişim halinde olabilmeleridir. Çünkü yaşanılan çağ bir iletişim ve bilgi çağı olduğundan iletişim, insanlar, gruplar ve kurumlar arasında anlaşma sağlayan bir köprü olarak karşımıza çıkmaktadır (Sabuncuoğlu ve Gümüş, 2008). Dolayısıyla turizm endüstrisinde çalışanların hem birbiriyle hem de turistlerle olumlu duygular oluşturabilmesinde kendilerini bir bütünün parçası olarak görmeleri ve iletişim kurmaları oldukça önemli bir yere sahiptir. Özellikle güzergâh boyunca tüm işleyişten sorumlu olan yat kaptanları, can-mal ve çevre güvenliğini sağlarken mürettebat ve turistlerle sıklıkla iletişim halindedirler. Bu sebeple yat kaptanlarının işte kendilerini değerli hissetmeleri işin sürdürülebilirliği açısından çok önemlidir. Çünkü, çalışanların işe yabancılaşması, diğer bir deyişle, taşıdığı amaçlar, benimsediği ilkelerle çelişirse ve ilişkiler ağı içerisine düşmesi durumu gerçekleşirse (Demir ve Acar, 1993) yat kaptanları iletişime kapalı hale gelebilir.

Yat turizminin önemli değerlerinden biri olan ve ticari yat mürettebatı hiyearşisinde en üst mevkide yer alan yat kaptanlarının, etkin olamaması, işine karşı ilgisizleşmesi, işle bütünleşememesi, iletişim kopukluğu, işten keyif, doyum alamama gibi durumları yaşaması onların işe yabancılaşmasına sebep oluşturabilir. Bununla birlikte yapılan araştırmalar, göstermektedir ki çalışanların işe yabancılaşma düzeyleri artıkça, işten ayrılma niyetleri artmakta ve performansları azalmaktadır. Nitekim, Banai, Reisel ve Probst, (2004) tarafından yapılan çalışmada, Kanungo'nun (1979), tanımladığı yabancılaşma kavramına açıklık getirilmiş ve yabancılaşma, "işin bireyin ihtiyaç ve beklentilerini karşılama potansiyeline sahip olmadığı" algılandığı sürece işten psikolojik açıdan ayrılma durumu olarak ifade edilmiştir. Hackman ve Oldham, (1975), ise çalı̧̧ma ortamına ilişkin algıların çalışanların tutumlarını etkilediği ve bu nedenle iyi tasarlanmış bir işin çalışanları daha fazla memnun edeceğini ifade etmektedir. Böylelikle, çalışma performansları olumlu yönde etkilenen çalışanların işe yabancılaşma hislerinin azaldığı belirtilmektedir. Chiaburu, Thundiyil ve Wang (2014) tarafından yapılan meta-analiz sonucunda, yabancılaşma ile işten ayrılma niyeti arasında pozitif yönlü güçlü bir bağ olduğunu, çalışan performansının ise yabancılaşmada güçlü bir belirleyici olduğunu gösteren veriler elde edilmiştir. Benzer şekilde, Golden, Veiga ve Dino (2008), yabancılaşmış çalışanların ihtiyaçları daha az yerine getirildiğinden ve örgütte kalmak için daha az neden olduğundan yabancılaşma ile işten ayrılma niyeti 
arasında olumlu bir ilişki olduğunu ifade etmiştir. Armstrong-Stassen (2006) ise yabancılaşmanın çalışanlararası iletişimi zedelediğine ve çalışma performansını azalttığına değinmiştir.

Yabancılaşma olgusu, önemsenmediği takdirde performans düşüklüğü, motivasyon kaybı, iş memnuniyetsizliği, bağlılığın azalması, iş-aile yaşam çatışması, duygusal sağırlık, örgütsel sinizm olmak üzere aşamalı olarak işten ayrılmaya kadar doğrudan ya da dolaylı olarak olumsuz sonuçlara sebep olabilmektedir (Arnold, 1985; Hirschfeld ve Feild, 2000; Sevinc ve Bagci, 2017). Bu nedenle yabancilaşma bir çok disiplinde ele alınmış, turizm alanında da araştırmalara konu edilmiştir. Öyleki DiPietro ve Pizam (2008) yiyecek-içecek işletmesine yönelik yaptıkları araştırmada çalışanların yaşadığı yabancılaşma hislerini vurgulamış, Xue, Manuel-Navarrete ve Buzinde (2014) turizm alan yazında yabancılaşma kavramının önemini kavramsal açıdan değerlendirmiştir. Develioğlu ve Tekin (2012) otel işletmelerinde çalışanların işe yabancılaşmaları ile demografik özellikleri arasındaki ilişkiyi incelemiş, Tanrıverdi ve Kahraman (2016) genel lider-üye etkileşimi, etki, katkı ve profesyonel saygı düzeyi arttıkça işe yabancılaşma düzeyinin azaldığını tespit etmiştir. Bu bağlamda, yabancılaşma olgusunun turizm alanında farklı açılardan ele alındığı halde çalışan performansına ve işten ayrılma niyetine etkisine yönelik benzer vurguların yapıldığını, liderlik ile bağdaştırılarak kontrol odağına dolaylı olarak değinildiğini belirtmek mümkündür (Lee-Ross, 2013; Kim, 2014; Pang, Kucukusta ve Chan 2015; Tao, Jiang, Liu, Yang, Zhang ve Zhang, 2017; Demir, Ayas ve Yildiz, 2018; Shafique, Kalyar, ve Ahmad, 2018) Buradan hareketle, yat kaptanlarının işe yabancılaşmalarının işten ayrılma niyetine etkisine yönelik aşağıda yer alan hipotez geliştirilmiştir;

Hipotez 1: Yat kaptanlarında işe yabancılaşma, işten ayrılma niyetini pozitif yönde etkiler.

Çalışanlar, çalışma ortamındaki olumlu ya da olumsuz tüm değişkenlerden doğrudan etkilenmektedir. Performans düşüklüğüne sebep olduğu savunulan yabancılaşma, bireylerin, yaşamdan kendini soyutlama, güçsüzleşme, giderek yalnızlaşma, yaşamın anlamını yitirme, çevreden izole olma gibi farklı kavramlarla tanımlanmaktadır (Usta ve Küçükaltan, 2014) Turizm işletmelerinde hizmeti sunan çalışanlar ile hizmet bekleyen müşteriler birebir iletişim kurmaktadır. Bu nedenle çalışanların yüksek performans, motivasyon artışı, örgüte olan bağlılığının artması gibi olumlu davranış sergilemesinde, müşteri memnuniyetinin oluşmasında ve örgütsel başarıya ulaşılmada önemli rol oynamaktadır (Aslan, Özkoç ve Çalışkan, 2015). Turizm işletmelerinde çalışma ortamı çalışanların sağlığını etkileyebildiği gibi, çalışanların sağlığı da çalışma ortamını etkileyebilmektedir. Özellikle emek yoğun işletmelerde hizmetin kalitesi doğrudan çalışanların performansıyla ilişkili olduğundan turizm işletmelerinde kaliteli hizmetin sunulması çalışanların verimli olmasına, çalışanların verimli olmaları ise fiziksel ve psikolojik yönden sağlıklı olmalarına bağlıdır (Tükeltürk, Şahin ve Yılmaz, 2014). Buradan hareketle, işten tatmin olamama, devamsızlık yapma, bağlılığın azalması, tükenmişlik, moral ve motivasyon düşüklüğü, yalnızlaşma gibi örgütsel ve bireysel sonuçlara neden olan yabancılaşma, işgörenlerin tutum ve davranışlarından mevcut ve potansiyel turistlere yansımaktadır. Özellikle turizm işletmelerinde, müşteri memnuniyetine zarar vermesi, ekip çalışmasına engel teşkil etmesi sebebiyle işe yabancılaşma, bireyler ve örgütler açısından gözardı edilmemesi gereken bir sorun olarak algılanmaktadır. Aynı zamanda, bireylerin güç kaynağını yorumlayış tarzı olarak tanımlanan kontrol odağı (Rotter, 1966) ile ilişkilendirilen çalışan performansına olumlu ya da olumsuz etkisi yansıyabilir.

\subsection{Kontrol Odă̆ı ve Düzenleyici Etkisi}

Bir kişilik özelliği olan kontrol odağı, sosyo-psikoloji dahil olmak üzere hemen hemen psikolojinin her alanında araştırma konusu olmuştur (Wang, Bowling ve Eschleman, 2010). Bireylerin amaçları doğrultusunda beklentiye sahip oldukları, bu beklentilerinin ise tutum ve davranışlara yansıdığı varsayılmaktadır (Rossier, Dahourou ve McCrae, 2005). Araştırmalardan elde edilen verilere göre, kontrol odağı, bir kişilik özelliği olması sebebiyle, bireyleri birbirinden farklı kılmakta, kontrol odağı inancı, çalışanların davranışlarını etkilemektedir (Rotter, 1966; Judge ve Bono, 2001; Banai vd., 2004). Alanyazın incelendiğinde kontrol odağ1 ölçeğinin birçok araştırmada örgütsel açısından değerlendirildiği (Spector, 1988), çalışan performansı, motivasyon, işten ayrılma niyeti, işe yabancılaşma olmak üzere farklı yaklaşımlarla ilişkilendirildiği görülmektedir (Silvester, Anderson-Gough, Anderson ve Mohamed, 2002; Banai vd. 2004; Ng, Sorensen ve Eby, 2006; Tutar, 2010). Ayrıca, kontrol odağının iş ortamında önemli bir role sahip olduğu, iş tatmini, çalışan performansı dâhil olmak üzere olumlu sonuçlar elde edildiği tespit edilmiştir (Judge ve Bono; 2001).

Kontrol odağı, bireylerin kendi kaderlerini kontrol ettiklerine inandıkları ölçüde iki farklı düzeyde sınıflandırılmaktadır. Çünkü, bireylerin olaylara bakış açıları ve olayları algılamaları, kontrol odağının 
boyutları olan içsel ve dışsal kontrol odağının düzenleyici etkisini yansıtmaktadır (Breet, Myburgh ve Poggenpoel, 2010) İçsel kontrol odağı, bireylerin elde ettiği sonuçlara dair kontrolün kendilerine bağlı olduğu inancına sahip olmayı ifade etmektedir. Diğer bir deyişle, içsel kontrol odağı olan kişiler davranışlarının sonuçlarını, kader, şans ya da başkalarının yardımıyla değil kendilerinin göstermiş olduğu çabaya bağlamaktadırlar. (Martin, Thomas, Charles, Epitropaki ve McNamara, 2005). Dolayısıyla, içsel kontrol odağa sahip çalışanlar, kendi tutum ve davranışlarını ön plana çıarırken, dışsal kontrol odağa sahip çalışanlar ise kendisi ile ilgili gelişmeleri dahi kendilerinden daha güçlü olanlara, şansa veya kadere dayandırmaktadır (Rotter, 1966). İçsel kontrol odağına sahip bireyler, iş koşulları üzerinde etkili, amaçlarına ulaşmada başarılı olmaya eğilimli, eylemleri ile sonuçları arasında güçlü bağları olan, iletişıme açık ve dış çevreyi kontrol etmeye yönelimlidir (Spector, 1988; Ng vd., 2006). Dışsal kontrol odağına sahip olan bireyler ise daha çok önceden belirlenen amaç ve hedeflere uyum sağlayan, sorgulamayan ve idare edilmesi daha kolay bireyleri ifade etmektedir (Spector, 1988). Dolayısıyla başarıyı veya başarısızlığı kendi yeteneklerine bağlayan bireyler içsel kontrol odaklı; kadere veya yapılan işin zorluğu gibi çevresel faktörlere bağlayanlar ise dişsal kontrol odaklı olarak nitelendirilmektedir (Weiner, Heckhausen, Meyer ve Cook, 1972). Bu bağlamda kontrol odağının, öz değerlendirmenin kritik öğelerinden biri olduğu anlaşılmaktadır (Judge ve Bono, 2001; Ng vd. 2006). Spector (1988) tarafından ise içsel kontrol odağına sahip çalışanların, dışsal kontrol odağına sahip çalışanlara göre çok daha fazla motivasyona, iş tatminine, liderlik düzeyine ve çalışan performansına sahip olduğunu ifade etmektedir. Cengil'e (2004) göre kontrol odağı öğrenilebilen ve geliştirilebilen bir kişilik özelliği olup dışsal kontrol odaklıktan, içsel kontrol odaklığa doğru dönüşümler olabilmektedir. Yorulmaz ve Alnıpak (2019) denizcilik meslek lisesi gemi yönetimi ve gemi makineleri alanı öğrencileri ile yaptıkları çalışmada, denizcilik öğrencilerinin dışsal kontrol odak düzeylerinin daha yüksek olduğunu rapor etmişler ve özellikle öğrencilere gemi kullanma ve makine dairesi simülatörleri eğitimlerinde mesleki sorumluluklar kazandıracak içerikli senaryolarda eğitimler yaptırılmasının dışsal odaklıktan içsel odaklığa doğru kaymalar sağlayabileceğini vurgulamışlardır. Banai ve arkadaşları (2004) yaptıkları çalışmada, kontrol odağı ile işe yabancılaşma arasında negatif yönlü, liderlik ve örgütsel bağlılık ile pozitif yönlü bir ilişki tespit etmişlerdir. Bunun yanı sıra kontrol odağının düzenleyici etkisini ortaya çıkartmak için Chiaburu ve arkadaşları (2014) tarafından yapılan çalışmada, kontrol odağının, işe yabanclaşmada belirleyici etkisinin olduğu belirlenmiştir. İşe yabancılaşmanın çıktısı olarak ise işten ayrılma niyeti ile çalışan performansı arasındaki ilişkinin varlığı tespit edilmiştir. Kanungo, (1982) ise kontrolü sınırlayan zorlayıcı bir dış gücün varlığının bireyi yabancılaşmaya yönelttiğini, iş ortamındaki bireysel özerkliği, kontrolü ve gücün varlığını işteki yabancılaşma durumunu ortadan kaldırmanın temel ön koşulu olarak sunmaktadır. Bu bağlamda kontrol odağının işe yabancılaşmaya yönelik düzenleyici etkisinin olduğuna değinmektedir. Nazariadli (2017) çalışan performansına etkisini belirlemek için iş tatminini, iş stresini ve kontrol odağını birarada analiz etmiştir. Salazar, Hubbard ve Salazar (2002) ise otel yöneticilerinin sahip oldukları kontrol odaklarını belirleyerek iş tatminine etkisini araştırmayı amaçlamış, çalışanların performansına ve işten ayrılma niyetlerine değinmiştir. Huang (2006) tarafından Tayvan mutfak sanatları çalışanlarına yönelik yapılan çalışmada, erkek çalışanların daha fazla içsel kontrol odağına sahip olduğu belirlenmiş, içsel kontrol odaklı çalışanların iş stresi ve ayrılma niyeti ile anlamlı negatif bir ilişkinin varlığ tespit edilmiştir. Çalışanların çevreleriyle iletişim kurarken hislerini ve düşünceleri farklı yansıtması halinde kendilerine yabancılaştıklarını göstermektedir (Develioğlu ve Tekin, 2013). Çünkü, iradeleri dışında sergiledikleri davranışlar, işten tatmin olamamalarına neden olmaktadır. Zamanla duygu yabancılaşması ise işe yabancılaşmaya dönüşmesine sebep olmaktadır. Bu sebeple, özellikle kendi iradeleri ile hareket edebilen, yeteneklerini işe yansıtabilen çalışanlar işe yabancılaşma durumunu yaşamayacak ve çalışma performansı artacaktır. Fakat yetenek ve becerilerini kullanamayan çalışanlar, güçsüz ve anlamsız hissederek işe yabancılaşmaları sonucunda işten ayrılmalarına zemin oluşacaktır. Dolayısıyla yönetimin yabancılaşmayı tanımlaması ve hemen ardından yabancılaşmaya neden olan faktörlerin belirlenmesi ve gerekli düzenlemeleri yapması gerekmektedir. İşe yabancılaşma, yat kaptanlarının örgütsel süreçlerdeki kontrolünü kaybetmesi, kendisini ifade edememesi ve işine karşı güçsüzlük hissi duyması sonucunda oluşmaktadır. Bununla birlikte, yat kaptanlarının çalışma alanlarında kontrol yetkisine sahip olmaması, işe yabancılaşma duygusunun oluşmasına sebep olmaktadır. Bu bağlamda Ceylan ve Sulu, (2010) çalışmalarında, bireyin işinde otonomiye ve işinin üzerinde kontrol yetkisine sahip olmamasının işe yabancılaşmaya neden olması açısından desteklemektedir. Buradan hareketle, yat kaptanlarının içsel ve dışsal kontrol odağı düzeylerinin, işe yabancılaşma ve işten ayrılma niyetine yönelik ele almak önem teşkil etmektedir. Buradan hareketle, yat kaptanlarının işe yabancılaşma, kontrol odağı ve işten ayrılma niyeti arasındaki ilişki ile bu 
ilişkide içsel ve dışsal kontrol odağının düzenleyici etkisini ortaya çıkartmaya yönelik aşağıdaki hipotezler geliştirilmiş ve Şekil 1'deki araştırma modeli oluşturulmuştur.

Hipotez 2: Yat kaptanlarının içsel ve dışsal kontrol odak düzeyleri arasındaki fark anlamlıdır.

Hipotez 3: Yat kaptanlarında içsel kontrol odă̆̆, işten ayrılma niyetini negatif yönde etkiler.

Hipotez 4: Yat kaptanlarında dışsal kontrol odağı, işten ayrılma niyetini pozitif yönde etkiler.

Hipotez 5: Yat kaptanlarında işe yabancılaşma ve işten ayrılma niyeti arasında içsel kontrol odağının düzenleyici etkisi vardir.

Hipotez 6: Yat kaptanlarında işe yabancılaşma ve işten ayrılma niyeti arasında dışsal kontrol odağının düzenleyici etkisi vardır.

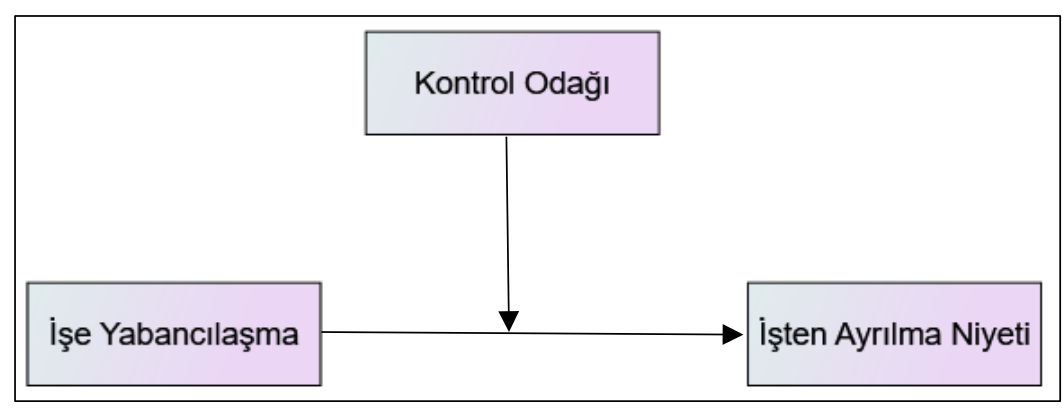

Şekil 1. Araştırma Modeli.

Şekil 1'deki araştırma modelinde, yat kaptanlarının işe yabancılaşmalarının, işten ayrılma niyetlerine etkisinde kontrol odağının düzenleyici etkisi gösterilmektedir.

\section{Yöntem}

Ticari yatlarda çalışan 390 yat kaptanından Nisan-Kasım 2019 tarihleri arasında yüz yüze anket tekniğiyle elde edilen veriler ile betimsel istatistikler, açıklayıcı ve doğrulayıcı faktör analizleri, geçerlilik ve güvenilirlik analizleri, korelasyon analizleri ile hiyerarşik regresyon analizleri SPSS 22 ve AMOS 22 istatistiksel paket programları yardımıyla yapılmıştır.

\subsection{Veri Toplama Araçları}

Araştırmada veri toplama aracı olarak kullanılan anket formu iki bölümden oluşmaktadır. Birinci bölümde araştırmaya katılan yat kaptanlarının demografik özelliklerine yönelik sorular yer almaktadır. İkinci bölümde ise yat kaptanlarının işe yabancılaşmalarını, işten ayrılma niyetlerini ve kontrol odaklarını belirlemeye yönelik olan ve 5'li Likert derecelendirme sistemi esas alınarak hazırlanmış üç ölçek bulunmaktadır.

İşe yabancılaşma ölçeği, Hirschfeld ve Feild (2000) tarafından geliştirilen ve Özbek'in (2011) çalışmasında Türkçeye uyarladı ̆̆ı on maddelik ölçektir ( $1=$ Kesinlikle katılmıyorum; $5=$ =Kesinlikle katılıyorum). Yat kaptanlarının işe yabancılaşma düzeylerini ölçmek için kullanılan ölçekte; "İş yaşamının çoğu anlamsız aktivitelerle heba olmaktadır" ve "İnsanların çalışmalarının asıl nedeninin topluma faydalı bir iş yapma düşüncesinin olduğuna pek inanamıyorum" gibi ifadeler yer almaktadır. Ölçeğin yapısal geçerliliğini belirlemek için yapılan açıllayıcı faktör analizinde (AFA) verilerin faktör analizi yapmak için (KMO: 0,928; $\chi 2: 2051,242 ; \mathrm{df:} 120$; $\mathrm{p}<$ ,001) yeterli olduğu, ölçeğin tek boyutlu faktör yapısına sahip olduğu ve toplam varyansın \% 55,07'sini açıklandığı anlaşılmış ve sonuçları Tablo 1'de verilmiştir. Açıklayıcı faktör analzinden sonra yapılan doğrulayıcı faktör analizinde (DFA) işe yabancılaşma ölçeğinin uyum indekslerinin ( $\chi 2$ /df: 2,974; GFI: 0,956; CFI: 0,969; IFI: 0,969; RMSEA: 0,071) kabul edilebilir değerler arasında olduğu (Hu ve Bentler 1999; MacCallum, Browne ve Sugawara 1996) ve Tablo 2'de de faktör yüklerinin tamamının 0,50'den ve $t$ değerlerinin ise 1,96'dan büyük ve anlamlı oldukları görülmektedir. Ayrıca ölçeğin benzeşme geçerliliğini belirlemek için de doğrulayıcı faktör analizinde Çıkarılan Ortalama Varyans (Average Variance Extracted AVE) ve Birleşik Güvenilirlik (Composite Reliability-CR) katsayıları hesaplanmış ve sonuçları Tablo 2'de verilmiştir. Tablo 2'den gözlenen değişkenlere ait standardize edilmiş $\beta$ katsayılarının her birinin 0,50 'den ve AVE değerlerinin de kritik değer olan 0,50 'den büyük olduğu görülmektedir. Bunların yanısıra CR katsayılarının da kritik değer olan 0,70'den büyük ve aynı şekilde tüm CR katsayılarının AVE değerlerinden 
de büyük olması nedeniyle de ölçüm modelinin benzeşme geçerliliğini sağladığı tespit edilmiştir (Fornell ve Larcker 1981, Hair vd. 2010). Güvenilirlik analizinde ise Cronbach's Alpha katsayısının 0,906 olduğu ve CR katsayısının da 0,834 olduğu ortaya çıkmıştır. Bunlara göre işe yabancılaşma ölçeğinin geçerli ve güvenilir bir ölçek olduğu söylenebilir.

İşten ayrılma niyeti ölçeği olarak Grandey'in (1999) çalışmasında kullandığı ve Özbek (2007) tarafından Türkçeye uyarlanan dört maddelik ölçek kullanılmıştır (1=Asla; $5=$ Daima). Tablo 1'de verilerin AFA yapmak için yeterli olduğu (KMO: 0,712; $\chi 2$ : 760,126; df: 3; p<,001), ölçeğin tek boyutlu faktör yapısına sahip olduğu ve toplam varyansın \% 82,35'inin açıklandığı anlaşılmaktadır. İşten ayrılma niyeti ölçeğinin DFA uyum indekslerinin $\left(\mathrm{x}^{2} / \mathrm{df}=0,348 ; \mathrm{GFI}=0,996 ; \mathrm{CFI}=0,999 ; \mathrm{IFI}=0,998\right)$ kabul edilebilir değerler arasında yer aldığ $(\mathrm{Hu}$ ve Bentler 1999; MacCallum, Browne ve Sugawara 1996) ve Tablo 2'de de faktör yüklerinin tamamının 0,50 'den ve $t$ değerlerinin ise $1,96^{\prime}$ dan büyük ve anlamlı oldukları görülmektedir. Tablo 2'de gözlenen değişkenlere ait standardize edilmiş $\beta$ katsayılarının her birinin 0,50 ' den ve AVE değerlerinin de kritik değer olan $0,50^{\prime}$ den büyük olduğu anlaşılmaktadır. Bunların yanısıra CR katsayılarının da kritik değer olan 0,70'den büyük ve aynı şekilde tüm CR katsayılarının AVE değerlerinden de büyük olması nedeniyle de ölçüm modelinin benzeşme geçerliliğini sağladığı tespit edilmiştir (Fornell ve Larcker 1981, Hair vd. 2010). Güvenilirlik analizinde ise Cronbach's Alpha katsayısının 0,822 olduğu ve CR katsayısının da 0,869 olduğu ortaya çıkmıştır. Bunlara göre işten ayrılma ölçeğinin geçerli ve güvenilir bir ölçek olduğu söylenebilir.

Tablo 1. Açıklayıcı Faktör Analizi Sonuçları.

\begin{tabular}{|c|c|c|c|c|c|c|c|}
\hline Ölçekler & Faktörler & KMO & $\begin{array}{l}\text { Barlett } \\
\text { Testi }\end{array}$ & $\begin{array}{l}\text { Soru } \\
\text { Say1S1 }\end{array}$ & $\begin{array}{l}\text { Faktör } \\
\text { Yükleri }\end{array}$ & \multicolumn{2}{|c|}{$\begin{array}{l}\text { Açıklanan } \\
\text { Varyans }\end{array}$} \\
\hline $\begin{array}{l}\text { İşe Yabancılaşma } \\
\text { Ölç̧eği }\end{array}$ & $\begin{array}{l}\text { İse } \\
\text { Yabancılaşma }\end{array}$ & ,928 & $\begin{array}{l}\chi 2: 2051,242 ; \\
\text { df:120; } p<, 001\end{array}$ & 10 & $\begin{array}{c}534 \\
- \\
, 844 \\
\end{array}$ & \multicolumn{2}{|l|}{55,07} \\
\hline $\begin{array}{l}\text { İşten Ayrilma } \\
\text { Niyeti Ölçeği }\end{array}$ & $\begin{array}{l}\text { İşten Ayrilma } \\
\text { Niyeti }\end{array}$ & ,712 & $\begin{array}{l}2: 760 \\
126 ; \\
d f: 3 ; p<, 001\end{array}$ & 4 & $\begin{array}{c}933 \\
- \\
, 826 \\
\end{array}$ & \multicolumn{2}{|l|}{82,35} \\
\hline \multirow[t]{2}{*}{$\begin{array}{l}\text { Kontrol Odağı } \\
\text { Ölçeği }\end{array}$} & $\begin{array}{l}\text { İçsel Kontrol } \\
\text { Odağı }\end{array}$ & \multirow[t]{2}{*}{,712 } & \multirow[t]{2}{*}{$\begin{array}{l}\chi 2: 1293,794 ; \\
d f: 28 ; p<, 001\end{array}$} & 4 & $\begin{array}{c}887 \\
- \\
, 703 \\
\end{array}$ & 34,60 & \multirow[t]{2}{*}{64,61} \\
\hline & $\begin{array}{l}\text { Dişsal Kontrol } \\
\text { Odağı }\end{array}$ & & & 4 & $\begin{array}{c}, 869 \\
- \\
, 632 \\
\end{array}$ & 30,01 & \\
\hline
\end{tabular}

Kontrol odağı ölçeği ise örgütsel bakış açısıyla ilk defa Spector'ın (1988) çalışmasında kullandığı ve Özgen vd.'nin (2014) Türkçeye uyarladıkları sekiz maddelik iş kontrol odağı ölçeğidir (1= Kesinlikle katılmıyorum; $5=$ Kesinlikle katıllyorum). Tablo 1'de verilerin AFA yapmak için yeterli olduğu (KMO: 0,712; $\chi 2$ : 1293,794; df: 28; p<,001), ölçeğin içsel kontrol odağı ve dışsal kontrol odağı olmak üzere iki boyutlu faktör yapısına sahip olduğu ve toplam varyansın \% 64,61'inin açıklandığı anlaşılmaktadır. Kontrol odağı ölçeğinin DFA uyum indekslerinin $\left(\mathrm{x}^{2} / \mathrm{df}=2,723 ; \mathrm{GFI}=0,977 ; \mathrm{CFI}=0,981 ; \mathrm{IFI}=0,981\right)$ kabul edilebilir değerler arasında olduğu (Hu ve Bentler 1999; MacCallum, Browne ve Sugawara 1996) ve Tablo 2' de faktör yüklerinin tamamının 0,50'den ve $t$ değerlerinin ise 1,96'dan büyük ve anlamlı oldukları görülmektedir. Tablo 2'de gözlenen değişkenlere ait standardize edilmiş $\beta$ katsayılarının herbirinin 0,50 'den ve AVE değerlerinin de kritik değer olan 0,50'den büyük olduğu anlaşılmaktadır. Bunların yanı sıra CR katsayılarının da kritik değer olan 0,70'den büyük ve aynı şekilde tüm CR katsayılarının AVE değerlerinden de büyük olması nedeniyle de ölçüm modelinin benzeşme geçerliliğini sağladığ1 tespit edilmiştir (Fornell ve Larcker 1981, Hair vd. 2010). Güvenilirlik analizinde ise içsel kontrol odağ 1 faktörünün Cronbach's Alpha katsayısının 0,738 olduğu ve CR katsayısının da 0,764 olduğu, dışsal kontrol odağı faktörünün de Cronbach's Alpha katsayısının 0,763 olduğu ve CR katsayısının da 0,789 olduğu ortaya çıkmıştır. Bunlara göre kontrol odağı ölçeğinin geçerli ve güvenilir bir ölçek olduğu söylenebilir.

Anket tekniğiyle elde edilen verilerin normal dağılıma uyup uymadığını anlamak için çarpıklık ve basıklık değerlerine bakılmış ve tüm gözlenen değişkenlere ait söz konusu değerler Tablo 2' de verilmiştir. Tablo 2' de 
M. Yorulmaz - F. Sevinç 12/2 (2020) 1524-1539

görüldüğü gibi tüm gözlenen değişkenler çarpıklık ve basıklık değerlerinin -2 ile +2 arasında olması nedeniyle verilerin normal dağılım gösterdiği (Kline, 2005) kabul edilmiştir.

Tablo 2. Doğrulayıcı Faktör Analizi Sonuçları.

\begin{tabular}{|c|c|c|c|c|c|c|c|}
\hline Faktörler & $\begin{array}{l}\text { Gözlenen } \\
\text { Değişkenler }\end{array}$ & Std. $\beta$ & $\mathbf{t}$ & Çarpıklık & Basıklık & AVE & CR \\
\hline \multirow[t]{10}{*}{ İşe Yabancılaşma } & İY1 &, 563 & - &, 523 &,- 331 & \multirow{10}{*}{,580 } & \multirow{10}{*}{834} \\
\hline & İY2 & 687 & $8,807^{* * *}$ & 150 &,- 976 & & \\
\hline & İY3 & 788 & $8,522^{* * *}$ & ,116 & $-1,099$ & & \\
\hline & İY4 & 775 & $8,467^{* * *}$ & ,161 & $-1,056$ & & \\
\hline & İY5 & 788 & $8,517^{* * *}$ & ,253 &,- 785 & & \\
\hline & İY6 & 846 & $8,711^{* * *}$ & 107 &,- 853 & & \\
\hline & İY7 & 802 & $8,572^{* * *}$ & ,028 &,- 867 & & \\
\hline & İY8 & 648 & $7,929^{* * *}$ & 376 &,- 465 & & \\
\hline & İY9 & ,714 & $8,237^{* * *}$ & 270 &,- 835 & & \\
\hline & İY10 &, 556 & $6,628^{* * *}$ &,- 223 &,- 803 & & \\
\hline \multirow{3}{*}{$\begin{array}{l}\text { İşten Ayrilma } \\
\text { Niyeti }\end{array}$} & İAN1 & ,924 & - & ,556 & ,675 & \multirow{3}{*}{ 698 } & \multirow{3}{*}{869} \\
\hline & İAN2 & ,920 & $17,830^{* * *}$ & 685 &,- 397 & & \\
\hline & İAN3 & ,732 & $17,840^{* * *}$ & 607 &,- 702 & & \\
\hline \multirow[t]{4}{*}{ İçsel Kontrol Odağ1 } & İKO1 & 664 & - & , 150 & ,985 & \multirow{4}{*}{0,511} & \multirow{4}{*}{0,764} \\
\hline & İKO2 & 615 & $12,596^{* * *}$ & ,336 &,- 851 & & \\
\hline & İKO3 & ,997 & $14,098^{* * *}$ & 084 &,- 955 & & \\
\hline & İKO4 & 665 & $13,372^{* * *}$ & ,379 &,- 811 & & \\
\hline \multirow[t]{4}{*}{ Dişsal Kontrol Odağı } & DKO1 & 824 & - &,- 995 & 1,856 & \multirow{4}{*}{, 582} & \multirow{4}{*}{ 789 } \\
\hline & $\mathrm{DKO} 2$ & 653 & $8,672^{* * *}$ &,- 872 & ,960 & & \\
\hline & DKO3 & 681 & $9,154^{* * *}$ &,- 741 & ,257 & & \\
\hline & DKO4 & ,900 & $11,757^{* * *}$ &,- 934 & ,458 & & \\
\hline
\end{tabular}

$* * * \mathrm{p}<0,001$

\subsection{Evren ve Örneklem}

Araştırmanın evrenini, Türk yat kaptanları oluşturmaktadır. Araştırma verileri, kolayda örneklem yöntemiyle Nisan-Kasım 2019 tarihleri arasında Marmara, Ege ve Akdeniz Bölgelerindeki marinalarda bulunan ticari yatlarda çalışan 390 yat kaptanından yüz yüze anket tekniğiyle toplanmıştır. Kline (2005) örneklem sayısının, ankette yer alan soru sayısının 10 katı ve bunun da en düşük 200 olması gerektiğini vurgulamaktadır. Anket formunda 22 maddenin bulunması ve araştırmada örneklem sayısının da 390 olmasıyla, yeterli sayıda örnekleme ulaşıldığı söylenebilir. 


\section{Bulgular}

\subsection{Betimsel İstatistikler}

Araştırmaya katılan yat kaptanlarının demografik özellikleri Tablo 3'te gösterilmiştir. Tablo 3'te yat kaptanlarının \% 74,3'ü (290 kişi) erkek, \% 34,9'u (136 kişi) 35-44 yaş aralığında, \% 50'si (195 kişi) lise mezunu, \% 30,3'ü (118 kişi) 4-7 yıl arasında iş deneyimine sahip ve \% 58,5'i (228 kişi) evli olduğu anlaşılmaktadır.

Tablo 3. Katılımcıların Demografik Özellikleri.

\begin{tabular}{|c|c|c|c|}
\hline Değişkenler & Gruplar & $n$ & $\%$ \\
\hline \multirow{3}{*}{ Cinsiyet } & Kadın & 100 & 25,7 \\
\hline & \begin{tabular}{|l|} 
Erkek \\
\end{tabular} & 290 & 74,3 \\
\hline & Toplam & 390 & 100,0 \\
\hline \multirow{6}{*}{ Yaş } & $18-24$ & 35 & 9,0 \\
\hline & $25-34$ & 127 & 32,6 \\
\hline & $35-44$ & 136 & 34,9 \\
\hline & $45-54$ & 66 & 16,9 \\
\hline & 55 ve üzeri & 26 & 6,7 \\
\hline & Toplam & 390 & 100,0 \\
\hline \multirow{5}{*}{ Eğitim Durumu } & İlkokul & 12 & 3,1 \\
\hline & Ortaokul & 51 & 13,1 \\
\hline & Lise & 195 & 50,0 \\
\hline & Üniversite & 144 & 36,9 \\
\hline & \begin{tabular}{|l|} 
Toplam \\
\end{tabular} & 390 & 100,0 \\
\hline \multirow{7}{*}{ İş Deneyimi } & 3 yıl ve altı & 113 & 29,0 \\
\hline & 4-7 y1l & 118 & 30,3 \\
\hline & $8-11$ yıl & 89 & 22,8 \\
\hline & $12-15$ yil & 29 & 7,4 \\
\hline & 16-19 y1l & 27 & 6,9 \\
\hline & 20 yıl ve üzeri & 14 & 3,6 \\
\hline & \begin{tabular}{|l|} 
Toplam \\
\end{tabular} & 390 & 100,0 \\
\hline \multirow{3}{*}{ Medeni Durumu } & Evli & 228 & 58,5 \\
\hline & Bekar & 162 & 41,5 \\
\hline & \begin{tabular}{|l} 
Toplam \\
\end{tabular} & 390 & 100,0 \\
\hline
\end{tabular}

\subsection{Hipotezlerin Testi}

Araştırma değişkenlerinin ortalama, standart sapma ve Pearson korelasyon katsayılarının yer aldığı Tablo 4'te dişsal kontrol odağ ile işe yabancılaşma ( $r: 0,350 ; p<0,01)$ ve işten ayrılma niyeti arasında $(r: 0,470 ; p<0,01)$ orta düzeyde, anlamlı ve pozitif yönlü bir ilişki olduğu anlaşılmaktadır. Ayrıca içsel kontrol odağı ile işe yabancılaşma (r: -0,129; $p<0,05)$, ve işten ayrılma niyeti arasında (r: -0,209; $p<0,01)$, düşük düzeyde, anlamlı ve negatif yönlü bir ilişki olduğu Tablo 4'te görülmektedir. Aralarında negatif yönlü ilişki bulunan içsel kontrol odağı $(X: 4,09)$ ve dışsal kontrol odağ $1(X: 2,70)$ ortalamaları arasındaki farkın anlamlı olup olmadığını tespit etmek için bağımlı örneklem $t$ testi yapılmıştır. Bağımlı örneklem $t$ testi bulgularına göre (t: 21,309; df: 389; $\mathrm{p}<0,001$ ) yat kaptanlarının içsel ve dışsal kontrol odakları ortalamaları arasındaki fark istatistiksel açıdan anlamlıdır. Diğer bir ifade ile araştırmaya katılan yat kaptanları içsel kontrol odaklı bireylerdir. Bu bulgulara göre Hipotez 2 kabul edilmiştir. 
Tablo 4. Değişkenlerin Ortalama, Standart Sapma ve Korelasyon Katsayıları.

\begin{tabular}{|l|l|l|l|l|l|l|}
\hline Değişkenler & Ort. & SS & $\mathbf{1}$ & $\mathbf{2}$ & $\mathbf{3}$ & $\mathbf{4}$ \\
\hline 1.İşe Yabancılaşma & 2,895 &, 855 & 1 & & & \\
\hline 2.İşten Ayrılma Niyeti & 2,283 & 1,075 &, $470^{* *}$ & 1 & & \\
\hline 3.İçsel Kontrol Odağ1 & 4,092 &, 667 &,$- 129^{*}$ &,$- 209^{* *}$ & 1 & \\
\hline 4.Dişsal Kontrol Odağ1 & 2,707 &, 981 &, $350^{* *}$ &, $310^{* *}$ &,$- 174^{* *}$ & 1 \\
\hline
\end{tabular}

${ }^{*} \mathrm{p}<0,05 ;{ }^{* *} \mathrm{p}<0,01$

Araştırmanın amacına yönelik olarak önerilen hipotezleri test etmek için yapılan Hiyerarşik Regresyon analizinin sonuçları Tablo 5 ve Tablo 6'da verilmiştir. Analiz kapsamında değişkenler arasında çoklu bağlantı problemi olmaması için bağımsız değişken olan işe yabancılaşma ve düzenleyici değişken olan içsel ve dışsal kontrol odağı değişkenleri standardize edilmiş ve yat kaptanlarının cinsiyet, yaş, eğitim durumu ve firmada çalışma süreleri kontrol değişkenleri olarak analizlere alınmıştır.

Tablo 5'te hiyerarşik regresyon analizinin birinci aşamasında, kontrol değişkenleri ile işe yabancılaşmanın, işten ayrılma niyeti üzerindeki etkisi incelenmiş ve işe yabancılaşmanın işten ayrılma niyetini (std. $\beta:, 471 ; p<$ 0,001; F: 19,101) pozitif yönde etkilediği anlaşılmaktadır. Bu bulgulara göre Hipotez 1 kabul edilmiştir. İkinci aşamada, kontrol değişkenleri ve işe yabancılaşma ile birlikte içsel kontrol odağı modele dahil edilmiş ve analiz sonucunda içsel kontrol odağının işten ayrılma niyeti üzerinde (std. $\beta$ : -,156; p< 0,01; F: 18,575; R2: 24) negatif yönde bir etkisinin olduğu ve işe yabancılaşma ile içsel kontrol odağının birlikte işten ayrılma niyetindeki değişimin \% 24'ünü açıkladığı ortaya çıkmıştır. Bu bulgulara göre Hipotez 3 kabul edilmiştir. Son aşama olan üçüncü aşamada ise kontrol değişkenleri, işe yabanclaşma, içsel kontrol odağı ile birlikte işe yabancılaşma ve içsel kontrol odağının çarpımı ile elde edilen etkileşim terimi/ düzenleyici değişken (İY*iKO) modele dahil edilmiş ve analiz sonucunda, etkileşim teriminin işten ayrılma niyeti üzerinde herhangi bir etkisinin (std. $\beta$ : ,002; p>0,05; F: 16,211) olmadığ ve $\Delta R^{2}$ bir değişimin de $\left(\Delta R^{2}: 0\right)$ olmadığı ortaya çıkmıştır. Etkileşim teriminin bağımlı değişken üzerinde bir etkisinin olmaması, düzenleyici etkinin olmadığını göstermektedir (Aiken, West ve Reno 1991; Baron ve Kenny 1986). Bu bulgulara göre Hipotez 5 reddedilmiştir.

Tablo 5. İşe Yabancılaşma ile İşten Ayrılma Niyeti Arasındaki İlişkide İçsel Kontrol Odağının Düzenleyiciliğine İlişkin Hiyerarşik Regresyon Analizi.

\begin{tabular}{|c|c|c|c|c|c|c|}
\hline \multirow{2}{*}{\begin{tabular}{|c|} 
Değişkenler \\
Bağımlı Değişken: İşten Ayrılma Niyeti
\end{tabular}} & \multicolumn{2}{|c|}{ I. Model } & \multicolumn{2}{|c|}{ II. Model } & \multicolumn{2}{|c|}{ III. Model } \\
\hline & Std. $\beta$ & $\mathbf{t}$ & Std. $\beta$ & $\mathbf{t}$ & Std. $\beta$ & $\mathbf{t}$ \\
\hline Cinsiyet &,- 063 & $-1,394$ &,- 075 & $-1,660$ &,- 075 & $-1,657$ \\
\hline Yaş & ,064 & ,988 & ,067 & 1,047 & ,067 & 1,044 \\
\hline Eğitim Durumu &,- 046 &,- 942 &,- 041 &,- 860 &,- 041 &,- 859 \\
\hline Firmada Çalışma Süresi &,- 078 & $-1,354$ &,- 070 & $-1,234$ &,- 070 & $-1,230$ \\
\hline Medeni Durumu &,- 003 &,- 047 &,- 011 &,- 200 &,- 011 &,- 194 \\
\hline İşe Yabancılaşma & 471 & $10,387^{* * * *}$ & 452 & $10,030^{* * *}$ & 452 & $9,477^{* * *}$ \\
\hline İçsel Kontrol Odağ & & &,- 156 & $-3,478^{* *}$ &,- 156 & $-3,472^{* *}$ \\
\hline Etkileşim Terimi (İ*iKO) & & & & & ,002 &, 040 \\
\hline $\mathrm{R}^{2}$ & \multicolumn{2}{|c|}{,230 } & \multicolumn{2}{|c|}{,254 } & \multicolumn{2}{|c|}{ 254 } \\
\hline Düzeltilmiş $\mathrm{R}^{2}$ & \multicolumn{2}{|c|}{,218 } & \multicolumn{2}{|c|}{,240 } & \multicolumn{2}{|c|}{ 238 } \\
\hline$\Delta \mathrm{R}^{2}$ & \multicolumn{2}{|c|}{,230 } & \multicolumn{2}{|c|}{,024 } & \multicolumn{2}{|c|}{,000 } \\
\hline F Değeri & \multicolumn{2}{|c|}{$19,101^{* * *}$} & \multicolumn{2}{|c|}{$18,575^{* * *}$} & \multicolumn{2}{|c|}{$16,211^{* * *}$} \\
\hline Çoklu Bağlantı İstatistikleri & \multicolumn{2}{|c|}{$\mathrm{VIF}<2$} & \multicolumn{2}{|c|}{$\mathrm{VIF}<2$} & \multicolumn{2}{|c|}{$\mathrm{VIF}<2$} \\
\hline
\end{tabular}

${ }^{*} \mathrm{p}<0,05 ;{ }^{* *} \mathrm{p}<0,01 ;{ }^{* * *} \mathrm{p}<0,001$

Tablo 6'da hiyerarşik regresyon analizinin ikinci aşamasında, kontrol değişkenleri ve işe yabancılaşma ile birlikte dışsal kontrol odağı modele dahil edilmiş ve analiz sonucunda dışsal kontrol odağının işten ayrılma niyeti üzerinde (std. $\beta$ : ,159; p< 0,01; F: 18,395) pozitif yönde bir etkisinin olduğu ortaya çıkmıştır. Bu bulguya 
göre Hipotez 4 kabul edilmiştir. Son aşama olan üçüncü aşamada ise kontrol değişkenleri, işe yabancllaşma, dışsal kontrol odağı ile birlikte işe yabancılaşma ve dışsal kontrol odağının çarpımı ile elde edilen etkileşim terimi (IY*DKO) modele dahil edilmiş ve analiz sonucunda, etkileşim teriminin/ düzenleyici değişkenin işten ayrılma niyeti üzerinde pozitif bir etkisinin (std. $\beta:, 126 ; \mathrm{p}<0,01 ; \mathrm{F}: 17,340$ ) olduğu ve $\Delta \mathrm{R}^{2} 0,015^{\prime}$ lik bir değişimin istatiksel açıdan anlamlı $\left(\Delta R^{2}:, 015 ; p<0,01\right)$ olduğu ortaya çıkmıştır. Etkileşim teriminin bağımlı değişken üzerinde bir etkisinin olması, düzenleyici etkinin olduğunu göstermektedir (Aiken, West ve Reno 1991; Baron ve Kenny 1986). Bu bulguya göre Hipotez 6 kabul edilmiştir.

Tablo 6. İşe Yabancılaşma ile İşten Ayrılma Niyeti Arasındaki İlişkide Dışsal Kontrol Odağının Düzenleyiciliğine İlişkin Hiyerarşik Regresyon Analizi.

\begin{tabular}{|c|c|c|c|c|c|c|}
\hline Değişkenler & \multicolumn{2}{|c|}{ I. Model } & \multicolumn{2}{|c|}{ II. Model } & \multicolumn{2}{|c|}{ III. Model } \\
\hline Bağımlı Değişken: İşten Ayrılma Niyeti & Std. $\beta$ & $\mathbf{t}$ & Std. $\beta$ & $\mathbf{t}$ & Std. $\beta$ & $t$ \\
\hline Cinsiyet &,- 063 & $-1,394$ &,- 053 & $-1,178$ &,- 049 & $-1,106$ \\
\hline Yaş & ,064 & 988 & 048 & ,741 & ,035 & ,551 \\
\hline Eğitim Durumu &,- 046 &,- 942 &,- 044 &,- 915 &,- 037 &,- 790 \\
\hline Firmada Çalışma Süresi &,- 078 & $-1,354$ &,- 072 & $-1,282$ &,- 065 & $-1,156$ \\
\hline Medeni Durumu &,- 003 &,- 047 & 001 & ,012 & ,007 & ,129 \\
\hline İşe Yabancılaşma & ,471 & $10,387^{* * *}$ & 414 & $8,637^{* * *}$ & 432 & $9,007^{* * *}$ \\
\hline Dişsal Kontrol Odağ 1 & & &, 159 & $3,336^{* *}$ & ,133 & $2,768^{* *}$ \\
\hline Etkileşim Terimi (IY*DKO) & & & & & , 126 & $2,774^{* *}$ \\
\hline $\mathrm{R}^{2}$ & \multicolumn{2}{|c|}{,230 } & \multicolumn{2}{|c|}{,252 } & \multicolumn{2}{|c|}{,267 } \\
\hline Düzeltilmiş $R^{2}$ & \multicolumn{2}{|c|}{218} & \multicolumn{2}{|c|}{,238 } & \multicolumn{2}{|c|}{252} \\
\hline$\Delta \mathrm{R}^{2}$ & \multicolumn{2}{|c|}{$230^{* * *}$} & \multicolumn{2}{|c|}{, $022^{* *}$} & \multicolumn{2}{|c|}{, $015^{* *}$} \\
\hline F Değeri & \multicolumn{2}{|c|}{$19,101^{* * *}$} & \multicolumn{2}{|c|}{$18,395^{* * *}$} & \multicolumn{2}{|c|}{$17,340^{* * *}$} \\
\hline Çoklu Bağlantı İstatistikleri & \multicolumn{2}{|c|}{$\mathrm{VIF}<2$} & \multicolumn{2}{|c|}{ VIF $<2$} & \multicolumn{2}{|c|}{$\mathrm{VIF}<2$} \\
\hline
\end{tabular}

${ }^{*} \mathrm{p}<0,05 ;{ }^{* *} \mathrm{p}<0,01 ;{ }^{* * *} \mathrm{p}<0,001$

Düzenleyici değişken olan dışsal kontrol odağının farklı düzeylerine (düşük, orta ve yüksek) göre işe yabancılaşma ve işten ayrılma niyeti arasındaki ilişkinin nasıl değiştiğini ortaya çıkartmak için standardize edilmemiş beta katsayıları kullanılarak yapılan basit eğim testi, Jose'nin (2013) online istatiksel programından faydalanırak yapılmış ve elde edilen grafik Şekil 2' de gösterilmiştir.

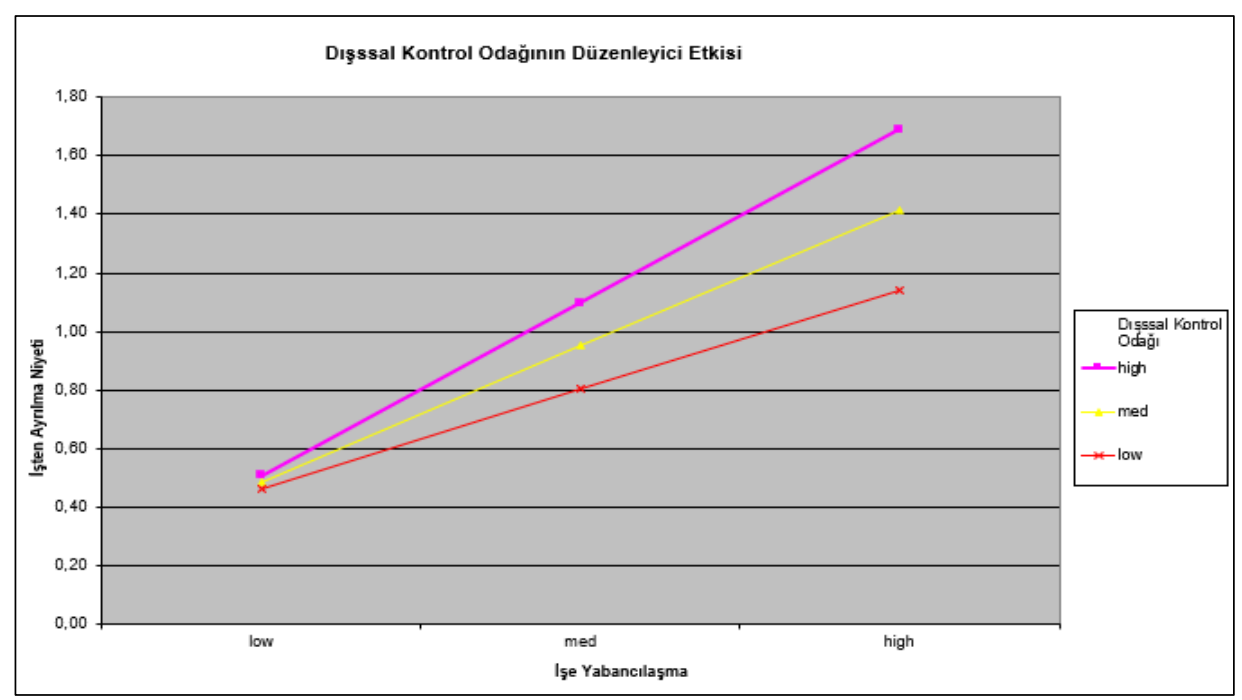

Şekil 2. İşe Yabancılaşma ile İşten Ayrılma Niyeti Arasındaki İlişkide Dışsal Kontrol Odağının Düzenleyici Etkisi.

Şekil 2 incelendiğinde, dışsal kontrol odağı doğrusunun eğimli olması ya da işten ayrılma niyeti ve işe yabancılaşma doğrularına parelel olmayışı, dışsal kontrol odağının işten ayrılma niyeti ve işe yabancılaşma 
arasında düzenleyici bir etkisinin olduğunu göstermektedir. Yat kaptanlarının dışsal kontrol odaklıklarının düşük, orta ve yüksek olma durumlarında işe yabancılaşma ve işten ayrılma niyetleri arasındaki ilişkinin seyri değişmektedir. Yat kaptanlarının dışsal kontrol odaklık düzeyleri arttıkça, işe yabancılaşmaları işten ayrılma niyetlerini daha fazla etkilemektedir. Diğer bir ifade ile yat kaptanlarının dışsal kontrol odaklı olmaları, işe yabancılaşmalarının işten ayrılma niyetlerine olan etkisini artırmaktadır.

\section{Sonuç ve Tartışma}

Örgüt kültürü, çalışma şartları, ekonomik, teknolojik, toplumsal ve kültürel faktörlerin etkilediği işe yabancılaşma, yat kaptanlarının işe yönelik performansları açısından önem teşkil etmektedir. Çünkü yat kaptanları çeşitli sebeplerle işten uzaklaşır, ilgisizleşir ve tüm bunların sonucunda işe yabancılaşırsa, yat turizminin en güçlü yapısı olarak örgüt yapısına zarar verebilir ve müşteri memnuniyetinde sorun yaşanabilir. Yat turizminin en önemli değerlerinden biri olan ve ticari yat mürettebatı hiyearşisinde en üst mevkide yer alan yat kaptanlarının işe yabancılaşması, işten ayrılma niyetlerini etkileyebilmektedir. Ayrıca, işe yabancılaşma hissinin bireysel bir kontrole bağlı olduğu inancına sahip olarak içsel kontrol odağının yansımaları mümkün olabilmektedir. Bununla birlikte, işe yabancılaşmanın, bireysel kontrolün dişında geliştiğine dair inanca sahip olarak dışsal kontrol odağının etkisi söz konusu olabilmektedir. Bu nedenle, mürettebatla ve turistlerle iletişimi sürekli ve yoğun olan yat kaptanlarının işe yabancılaşmaları işletmenin hedeflerine ulaşmasında engel teşkil edebilir, çalışma ortamını olumsuz etkileyebilir ve müşteri memnuniyetsizliğine sebep olabilir. Bu olgulardan yola çıkarak yat kaptanlarının işe yabancılaşma, işten ayrılma niyeti ve kontrol odakları arasındaki ilişkilerin incelendiği bu araştırmada, ticari yatlarda çalışan 390 yat kaptanından yüz yüze anket tekniğiyle elde edilen veriler yardımıyla analiz edilmiştir. Çoğunluğunun erkek, 35-44 yaş aralığında, lise mezunu ve 4 ile 7 yıl arasında iş deneyimine sahip yat kaptanlarından elde edilen verilerin analizinde betimsel istatistikler, açılayıcı ve doğrulayıcı faktör analizleri, korelasyon analizi, güvenilirlik analizi, bağımlı örneklem $t$ testi, hiyerarşik regresyon analizleri ve basit eğim testleri kullanılmıştır.

Araştırma bulgularına göre, yat kaptanlarının içsel odak ortalamalarının dışsal odak ortalamalarından daha yüksek olduğu ve bunun istatistiksel açıdan da (t: 21,309; df: 389; $p<0,001$ ) anlamlı olduğu, işe yabancılaşmanın (std. $\beta$ : ,471; $p<0,001$ ) işten ayrılma niyeti üzerinde, hem içsel kontrol odağının (std. $\beta$ : -,156; $\mathrm{p}<0,01$ ) hem de dişsal kontrol odağının (std. $\beta$ : ,159; $p<0,01$ ) işten ayrılma niyeti üzerinde anlamlı etkilerinin olduğu ortaya çıkmıştır. Ayrıca işe yabancılaşma ve kontrol odağının, işten ayrılma niyetindeki değişimin \% 24 'ünü açıkladığı tespit edilmiştir. Bunlarla birlikte sadece dışsal kontrol odağının (std. $\beta$ : ,126; $p<0,01$ ) işe yabancılaşma ve işten ayrılma niyeti arasındaki ilişkide düzenleyicilik etkisinin olduğu bulgusuna ulaşılmıştır. Bu bulgulara göre önerilen altı araştırma hipotezinden beşi (Hipotez 1,2,3,4,6) kabul biri ise (Hipotez 5) reddedilmiştir. İşe yabancılaşma ve işten ayrılma niyeti arasındaki ilişkide dışsal kontrol odağının düzenleyici etkisinin olması, dışsal kontrol odağının yüksek olduğu durumlarda, işe yabancılaşmanın işten ayrılma niyetine olan etkisinin daha da fazla olduğunu göstermektedir. Diğer bir deyişle yat kaptanlarının dışsal kontrol odaklık düzeyleri artıkça, işe yabancılaşmaları işten ayrılma niyetlerini daha fazla etkilemektedir. Ayrıca yat kaptanlarının dışsal kontrol odaklık düzeylerinin yüksek olduğu durumlardaki işe yabancılaşmanın, işten ayrılma niyetlerine olan etkisi, dışsal kontrol odaklık düzeylerinin düşük olduğu durumlarından daha fazladır aynı şekilde yat kaptanları dışsal kontrol odaklı olduklarında ve işe yabancılaşma hissettikleri durumda işten ayrılma niyetleri daha da fazla olmaktadır.

Alan yazında araştırma konusu olan işe yabancılaşma, kontrol odağı ve işten ayrılma niyeti arasındaki ilişkilerin çeşitli disiplinlerce ele alındığı, denizcilik ve turizm çalışmalarında ise ayrı ayrı değerlendirilerek araştırmalara konu edildiği görülmektedir (Anafarta ve Yılmaz, 2019; Karakaş, 2017; Lefcourt, 2014; Tokmak, 2014; Tuna ve Yeşiltaş, 2014; Uysal ve Tayfun, 2019; Yıldırım ve Türker, 2018; Yorulmaz ve Alnıpak, 2019). Özellikle son yıllarda ön plana çıkan ve önemi kavranan yat turizmi çalışanları, yat kaptanları açısından söz konusu değişkenlerin değerlendirilmemiş olması önemli bir eksikliktir. Araştırmanın bu yönüyle literatürde önemli bir boşluğu dolduracağı düşünülmektedir. Ayrıca ticari yat işletmeciliği yapan denizcilik işletmelerinin yöneticileri, kontrol odaklılı̆̆ının öğrenilebilen ve geliştirilebilen bir kavram olduğu gerçeğinden yola çıkarak, istihdam ettikleri yat kaptanlarının dişsal kontrol odaklıklarının içsel kontrol odaklığa doğru değişebileceğini bilmeliler ve bunlara yönelik yönetsel faaliyetler içerisinde olmalıdırlar. Zira işe yabancılaşma yaşayan yat kaptanlarının dışsal odaklılık düzeyleri artıkça işten ayrılma niyetleri de o oranda artmaktadır. 


\section{Kaynakça}

Aiken, L. S., West, S. G. ve Reno, R. R. (1991). Multiple regression: Testing and interpreting interactions. Sage.

Anafarta, A., ve Yılmaz, Ö. (2019). Kariyer tatmini ve işten ayrılma niyeti arasındaki ilişkide işe adanmışlığın aracılık rolü, İşletme Araştırmaları Dergisi, 11(4), 2944-2959.

Armstrong-Stassen, M. (2006). Determinants of how managers cope with organisational downsizing. Applied Psychology, 55(1), 1-26.

Arnold, H. J. (1985). Task performance, perceived competence, and attributed causes of performance asdeterminants of intrinsic motivation. Academy of Management Journal, 28, 875-888.

Aslan, Z., Özkoç A. G. ve Çalışkan, N. (2015). Örgütsel ortamda haset. I. Avrasya Uluslararası Turizm Kongresi, Selçuk Üniversitesi, Konya, 20-25.

Banai, M., Reisel, W. D., ve Probst, T. M. (2004). A managerial and personal control model: Predictions of work alienation and organizational commitment in Hungary, Journal of International Management, 10(3), 375392.

Baron, R.M. ve Kenny, D. A. (1986). TheModerator- Mediator Variable Distinction in Social Psychological Research: Conceptual,Strategic and Statistical Considerations, Journal of Personality and Social Psychology, 51, 1173-1182.

Breet, L., Myburgh, C., ve Poggenpoel, M. (2010). The relationship between the perception of own locus of control and aggression of adolescent boys. South African journal of education, 30(4), 511-526.

Budd, J. W. (2011). Çalışma Düşüncesi, Çev. F. Man, İstanbul: Ayrıntı Yayınları.

Cengil, M. (2004). Gazi Üniversitesi Çorum İlahiyat Fakültesi Öğrencilerinin Denetim Odaklarının Çeşitli Değişkenlere Göre İncelenmesi. Gazi Üniversitesi Çorum İlahiyat Fakültesi Dergisi, 3(5), 65-88.

Ceylan, A. ve Sulu, S. (2010). Work Alienation as a Mediator of the Relationship of Procedural Injustice to Job Stress, International Journal of Business and Management, 5 (8), 65-74.

Chiaburu, D. S., Thundiyil, T., ve Wang, J. (2014). Alienation and its correlates: A meta-analysis. European Management Journal, 32(1), 24-36.

Dean, D. G. (1961). Alienation: Its Meaning and Measurement, American Sociological Review, 26(5), 753-758.

Demir, M., Ayas, S., ve Yildiz, B. (2018). Örgütsel Sinizm ve İşe Yabancılaşma İlişkisi: Beş Yıldızlı Otel Çalışanları Üzerine Bir Araştırma. Çanakkale Onsekiz Mart Üniversitesi Yönetim Bilimleri Dergisi, 16(32), 231.

Demir, Ö. ve Acar, M. (1993). Sosyal Bilimler Sözlüğü, İstanbul: Ağaç Yayınları.

Develioğlu K, Tekin Ö. A. (2012). Otel çalışanlarının yabacılaşma düzeyinin demografik özellikler kapsamında incelenmesi, Uluslararası Alanya İşletme Fakültesi Dergisi 4(3): 121-128.

DiPietro, R. B., ve Pizam, A. (2008). Employee alienation in the quick service restaurant industry. Journal of Hospitality ve Tourism Research, 32(1), 22-39.

Fiori, K. L., Brown, E. E., Cortina, K. S., Antonucci, T. C. (2006). Locus of Control as a Mediator of the Relationship between Religiosity and Life Satisfaction: Age, Race, and Gender Differences, Mental Health, Religion and Culture, 9(03), 239-263.

Fornell, C., ve D. F Larcker. (1981). Evaluating structural equation models with unobservable variables and measurement error., Journal of Marketing Research, 39-50.

Fromm, E. (1990). Sağlıklı Toplum, Çev. Y. Salman ve Z. Tanrısever, İstanbul: Payel Yayınevi.

Golden, T. D., Veiga, J. F., ve Dino, R. N. (2008). The impact of professional isolation on teleworker job performance and turnover intentions: Does time spent teleworking, interacting face-to-face, or having access to communication-enhancing technology matter?, Journal of Applied Psychology, 93(6), 1412. 
Hackman, J. R., ve Oldham, G. R. (1975). Development of the job diagnostic survey. Journal of Applied psychology, 60(2), 159.

Hair, J. F., W. C. Black, B. J. Babin, ve R. E. Anderson. Multivariate Data Analysis. Upper Saddle River, New Jersey: Prentice Hall, 2010.

Hirschfeld, R. R. ve Feild, H. S. (2000). Work Centrality and Work Alienation: Distinct Aspects of a General Commitment to Work, Journal of Organizational Behavior: The International Journal of Industrial, Occupational and Organizational Psychology and Behavior, 21 (7), 789-800.

Huang, H. I. (2006). Understanding culinary arts workers: Locus of control, job satisfaction, work stress and turnover intention, Journal of Foodservice Business Research, 9(2-3), 151-168.

Jose, P. E. (2013). ModGraph-I: A programme to compute cell means for the graphical display of moderational analyses: The internet version, Version 3.0. Victoria University of Wellington, Wellington, New Zealand. https://psychology.victoria.ac.nz/modgraph/ (Erişim tarihi: 12 Aralık 2019)

Judge, T. A., ve Bono, J. E. (2001). Relationship of core self-evaluations traits-self-esteem, generalized selfefficacy, locus of control, and emotional stability-with job satisfaction and job performance: A meta analysis. Journal of Applied Psychology, 86, 80-92.

Kanungo, R. N. (1979). The concepts of alienation and involvement revisited. Psychological Bulletin, 86(1), 119.

Kanungo, R. N. (1982). Work alienation: An integrative approach. ABC-CLIO.

Karakaş, A. (2017). Duygusal emek, tükenmişlik ve işten ayrılma niyeti arasındaki ilişki: Otel işletmesi çalışanları üzerine bir araştırma. İ̧̧letme Araştırmaları Dergisi, 9(1), 80-112.

Kaya, U., ve Serçeoğlu, N. (2013). Duygu İşçilerinde İşe Yabancllaşma: Hizmet Sektöründe Bir Araştırma, Çalısma ve Toplum, 36(1), 311-346

Kim, N. (2014). Employee turnover intention among newcomers in travel industry. International Journal of Tourism Research, 16(1), 56-64.

Kline, R. B. (2005). Principles and practice of structural equation modeling (2nd ed.). New York: Guilford Press.

Kohn, M. L. (1976). Occupational Structure and Alienation, American Journal of Sociology, 82 (1), 111-130.

Köksal, E. (2010). Kurumsal Yabancılaşma, Polis Bilimleri Dergisi, 12(2), 107-123.

Lee-Ross, D. (2013). Human resources management, service delivery and the job satisfaction/alienation paradox: a hospitality industry perspective. Asia-Pacific Journal of Innovation in Hospitality and Tourism, 2(2), 211-226.

Lefcourt, H. M. (2014). Locus of control: Current trends in theory ve research. Psychology Press.

Litze, H. ve Bentler, P. (1999). Cutoff criteria for fit indexes in covariance structure analysis: Conventional criteria versus new alternatives, Structural equation modeling: a multidisciplinary journal, 6 (1), 1-55.

MacCallum, R. C., Michael W. B., ve Hazuki M. S. (1996). Power analysis and determination of sample size for covariance structure modeling, Psychological methods, 1(2), 130-149.

Martin, R., Thomas, G., Charles, K., Epitropaki, O., ve McNamara, R. (2005). The role of leader-member exchanges in mediating the relationship between locus of control and work reactions. Journal of Occupational and Organizational Psychology, 78(1), 141-147.

McDermott, B. J. (2002). The Utility of Perceived Stress, Locus of Control, and Type A Behavior Pattern as Predictors of Doctoral Degree Completion in a Non-traditional Ed. D. Program (Yayımlanmamış Doktora Tezi). West Virginia University, ABD.

Nazariadli, S. (2017). The Trade-Offs between Job Satisfaction, Performance, and Locus of Control on Job Performance: Case of Sohana Outfitters Company. Journal of Tourism ve Hospitality, 6(1), 266-272. 
M. Yorulmaz - F. Sevinç 12/2 (2020) 1524-1539

Ng, T. W., Sorensen, K. L., ve Eby, L. T. (2006). Locus of control at work: a meta-analysis. Journal of Organizational Behavior, The International Journal of Industrial, Occupational and Organizational Psychology and Behavior, 27(8), 1057-1087.

Öz, E. A. (2007). Duygusal Emek Davranışlarının Çalışanların İş Sonuçlarına Etkisi, (1. Baskı), İstanbul: Beta Basım Yayım.

Özbek, M. (2011). Örgüt İçerisindeki Güven ve İşe Yabancılaşma İlişkisinde Örgüte Uyum Sağlamanın Aracı Rolü. Süleyman Demirel Üniversitesi İktisadi ve İdari Bilimler Fakültesi Dergisi, 16(1), s. 231-248.

Özgen, H.K.Ş., Kaygalak, S., Türksos S.S., Dilek, S.E., ve Tütüncü, Ö. (2014), VII. Lisansüstü Turizm Öğrencileri Araştırma Kongresi, “Konaklama İşletmelerinde İş Kontrol Odağı Analizi” Aydın, Kuşadası.

Özyurt, C. (2016). Erich Fromm'un İnsan ve Toplum Anlayışı, Modern Toplumun Çözümlenmesi, Ankara: Hece Yayınları.

Pang, L., Kucukusta, D., ve Chan, X. (2015). Employee turnover intention in travel agencies: Analysis of controllable and uncontrollable factors. International journal of tourism research, 17(6), 577-590.

Rockmore, T. (2002). Marksizmden Sonra Marx, Karl Marx'ın Felsefesi, Çev. H. Türker, İstanbul: Ayrıntı Yayınları

Rossier, J., Dahourou, D., ve McCrae, R. R. (2005). Structural and mean-level analyses of the five-factor model and locus of control: Further evidence from Africa. Journal of Cross-Cultural Psychology, 36(2), 227-246.

Rotter, J. B. (1966). Generalized expectancies for internal versus external control of reinforcement. Psychological Monographs: General and Applied, 80(1), 1-28.

Saatcıoğlu, F. ve Ukray, M. (2017). Karl Marx ve Das Kapital, Hayattı ve Das Kapital Üzerine bir İnceleme, Anakara: Yason Yayincilik.

Sabuncuoğlu, Z. ve Gümüş, M. (2008). Örgütlerde iletişim. İstanbul: Arıkan Yayıncılık.

Salazar, J., Hubbard, S., ve Salazar, L. (2002). Locus of control and its influence on hotel managers' job satisfaction. Journal of Human Resources in Hospitality ve Tourism, 1(2), 15-26.

Sayers, S. (2003). Creativ Activity and Alienation in Hegel and Marx, Historical Materyalism, 11(1), 107-128.

Seeman, M. (1967). On the Personal Consequences of Alienation in Work, American Sociological Review, 32(2), 273-285.

Sevinc, F., ve Bagci, E. (2017). Alexithymia and Its Evaluation With Regard to The Organizational Commitment In Tourism Industry. Young Economists Journal/Revista Tinerilor Economisti, 14(29), 42-51

Sevinç, F. ve Güzel, T. (2016). Yat turizmi T. F. Çakmak ve F. İstanbullu Dinçer (Ed.) Deniz turizmi içinde (ss. 89-156). Ankara: Detay Yayıncllı.

Shafique, I., N Kalyar, M., ve Ahmad, B. (2018). The Nexus of Ethical Leadership, Job Performance, and Turnover Intention: The Mediating Role of Job Satisfaction. Interdisciplinary Description of Complex Systems: INDECS, 16(1), 71-87.

Silvester, J., Anderson-Gough, F. M., Anderson, N. R., ve Mohamed, A. R. (2002). Locus of control, attributions and impression management in the selection interview. Journal of Occupational and Organizational Psychology, 75(1), 59-76.

Spector, P. E. (1988). Development of the work locus ofcontrol scale. Journal of Occupational Psychology, 61(4), 335-340.

Tanrıverdi, H., ve Kahraman, O. C. (2016). 5 Yıldızlı Otel İşletmelerinde Lider-Üye Etkileşimi ve İşe Yabancılaşma İlişkisi: Marmaris ve İstanbul Destinasyonlarında Bir Araştırma. Dokuz Eylül Üniversitesi Sosyal Bilimler Enstitüsü Dergisi, 18(3), 463-493.

Tao, J., Jiang, W., Liu, C., Yang, X., Zhang, W., ve Zhang, H. (2017). New employee intention to leave and consequent work performance: Does leadership style matter?. Social Behavior and Personality: an international journal, 45(10), 1707-1721. 
Tokmak, İ. (2014). Duygusal emek ile işe yabancılaşma ilişkisinde psikolojik sermayenin düzenleyici etkisi. İsletme Araştırmaları Dergisi, 6(3), 134-156.

Tolan, B. (1981). Çă̆daş Toplumun Bunalımı, Anomi ve Yabancılaşma, Ankara:Aitai Yayınları.

Tuna, M. ve Yeşiltaş, M. (2014). Etik iklim, işe yabancılaşma ve örgütsel özdeşleşmenin işten ayrılma niyeti üzerindeki etkisi: Otel işletmelerinde bir araştırma. Anatolia: Turizm Araştırmaları Dergisi, 25(1), 105117.

Tutar, H. (2010). İşgören Yabancılaşması ve Örgütsel Sağlık İlişkisi: Bankacılık Sektöründe Bir Uygulama, Ankara Üniversitesi SBF Dergisi, 65 (1), 175-204.

Tükeltürk, A. Ş., Şahin, D. ve Yılmaz, İ. A. (2014). Turizm işletmelerinde presenteeism (işte var olamama). İçinde Ş. A. Tükeltürk, N. Ş. Perçin ve B. Güzel (Ed.), Turizm çalışan ilişkileri yönetimi (ss.281-302). Ankara: Detay Yayıncilı.

Usta, I. ve Küçükaltan, D. (2014), Turizm İşletmelerinde Örgütsel Yabancılaşma, Ş. Aydın Tükeltürk, N. Şahin Perçin ve B. Güzel (Eds.) Turizm İşletmelerinde Çalışan İlişkileri Yönetimi, (ss.361-374). Ankara: Detay Yayıncilik.

Wang, Q., Bowling, N. A., ve Eschleman, K. J. (2010). A Meta-Analytic Examination of Work and General Locus of Control. Journal of Applied Psychology, 95(4), 761-768.

Weiner, B., Heckhausen, H., Meyer. W., ve Cook, R. (1972). Causal Ascriptions and Achievement Behavior: A Conceptual Analysis of Effort and Reanalysis of Locus of Control. Journal of Personality and Social Psychology, 21(2), 239-248.

Xue, L., Manuel-Navarrete, D., ve Buzinde, C. N. (2014). Theorizing the concept of alienation in tourism studies. Annals of Tourism Research, 44, 186-199.

Yıldırım, M., ve Türker, N. (2018). The effect of emotional labor on work alienation: A study at hotel businesses. Journal of Business Research Turk, 10 (3), 606-621.

Yorulmaz, M. ve Alnıpak, S. (2019). Gemi Yönetimi ve Gemi Makineleri Alanı Öğrencilerinin Kontrol Odaklarının Belirlenmesi. Journal of Social and Humanities Sciences Research, 6(42): 2716-2724. 